OPEN ACCESS

Edited by:

Alison Parker

Cranfield University, United Kingdom

Reviewed by:

Ruth Quinn,

The University of Sheffield,

United Kingdom

Jessica Eisma,

University of Texas at Arlington,

United States

*Correspondence:

M. W. Ertsen

m.w.ertsen@tudelft.n

tThese authors have contributed equally to this work and share first authorship

Specialty section:

This article was submitted to

Water and Climate,

a section of the journal

Frontiers in Water

Received: 04 March 2021

Accepted: 14 June 2021

Published: 14 July 2021

Citation:

Ertsen MW and Ngugi KN (2021) Ambivalent Assets: The Success of Sand-Storage Dams for Rainwater Harvesting in Kitui County, Kenya. Front. Water 3:676167.

doi: 10.3389/frwa.2021.676167

\section{Ambivalent Assets: The Success of Sand-Storage Dams for Rainwater Harvesting in Kitui County, Kenya}

\author{
M. W. Ertsen ${ }^{1 * t}$ and K. N. Ngugi ${ }^{2 \dagger}$ \\ ${ }^{1}$ Water Resources, Civil Engineering and Geosciences, Delft University of Technology, Delft, Netherlands, ${ }^{2}$ Department of \\ Hydrology and Aquatic Science, School of Environment, Water and Natural Resources Management, South Eastern Kenya \\ University, Kitui, Kenya
}

This paper assesses the success of sand-storage dams in Kitui, Kenya-with "success" being considered to relate to the amount of water that dams can store, and the usability of the water in terms of access, quantity and quality. Building on a series of recent larger and smaller research projects, the paper sketches the complex interactions between community involvement, water use, and hydrological processes. Catchment-wide processes (including infiltration and runoff) resulting in water retention and sustained flow in the seasonal rives need to be taken into account. At the same time, within a catchment and within communities, diversity between water users (for example in terms of access or values related to water) will be encountered. The interplays between all these different issues have to be studied in more detail, to support governments and communities developing water harvesting interventions like sand-storage dams.

Keywords: sand-storage dams, rainwater harvesting, asal, groundwater, interventions

\section{INTRODUCTION}

The need for rainwater harvesting in remote arid regions of the world cannot be understated. In Kenya, there have been several attempts to meet water demand though use of several technologies. At individual and community levels, rainwater harvesting is a promising technology, especially because government-facilitated water supply systems are rare. Rainwater harvesting is a relatively secure and self-sustaining way of self-preservation either at individual or community level. In the absence of adequate centralized systems of water provision, individuals can create their own systems, which they can easily manage and control through rain water harvesting. For Kitui County, Kenya (Figure 1), the most popular rainwater harvesting technology has been sand-storage dams (also often referred to as sand dams). These are impermeable barriers erected across seasonal sandy riverbeds. They function by impounding sand, flash flood water and subsurface flow following a rain event.

In this paper, we critically assess the success of the Kitui sand-storage dams program and sketch implications for both academic research and policy development. In doing so, we expand on Ertsen and Hut (2009), who discuss three related issues: 1) community involvement/ownership, 2) water use, and 3) hydrological processes. Since Ertsen and Hut (2009), many more papers have been published about sand-storage dams - with many using the Kitui case study — as shown in Figure 2. Using the relatively straightforward query of "sand-storage dams" (including variations of spelling) in the Delft University of Technology library search engine, and selecting for journal papers, yielded the distribution of papers over the last 50 years in the figure. The peaks in the periods 2006-2010 and in the last five years (2016-2020) are clearly visible. The dominating argument in these 


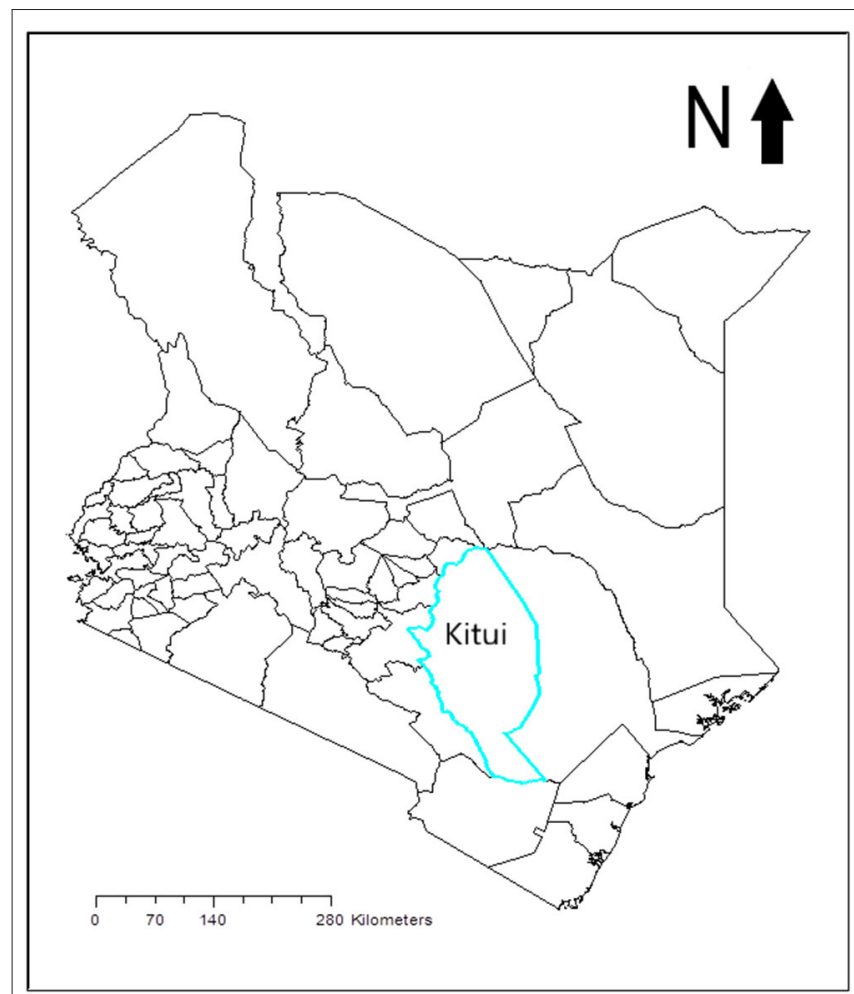

FIGURE 1 | Kitui County in Kenya.

publications is that sand-storage dams are very useful technologies. Especially in the first decade of the 2000s, the success story of Kitui sand dams became rather famous. As a result, several attempts have been made to study them and to bring the technology to other semi-arid regions. As such, the technology is spreading, with at least another 50 sand dams in other African counties, including Burkina Faso, Ethiopia, Tanzania and Uganda (Benedicto van Dalen et al., n.d.; see Ryan and Elsner, 2016).

We do not aim to discuss these processes of technology transfer themselves. Rather, we want to suggest that the successes of sand-storage dams need to be critically assessed-which could perhaps have consequences for successful technology transfer. We are able to expand on this issue compared to the earlier integrative work on sand dams by Ertsen and Hut (2009), using our own larger and smaller research engagements. These include a series of MSc thesis research projects by students of Delft University of Technology under the supervision of the first author, and the recently completed $\mathrm{PhD}$ thesis on sand-storage dams by the second author (see also Ngugi et al., 2020). It would be useful to stress two things. First, our paper does not aim to provide a detailed and thorough new understanding of challenges to success. In relation to this, as a second point, we are not the first people to suggest that sand-storage dams are less successful than occasionally hoped for. Already in Falkenmark et al. (2001), we find a reference to Nissen-Petersen (one of the main experts on sand-storage dams), who claims that in semi-arid parts of Kenya (without specifying more detail on locations), about $80 \%$ of the dams were not performing well. De Trincheria et al. (2018) explores sand dams' sedimentation processes for dams that have not been built in stages-although the procedure to build dams in stages is typically outlined in construction procedures for sandstorage dams. This concern is confirmed by Eisma and Merwade (2020), who encountered a layer of silt within the sand volume of a dam in Tanzania. The issue of building a dam in stages or not, and its effects, is also taken up by Ertsen and Hut (2009). They conclude that despite being built in a single season, many sand-storage dams in Kitui do not appear to have too much fine sediment. These mixed observations suggest that follow-up research on the issue of dam building procedures in relation to the sediments caught by the dam, is still required to improve on the success of sand dams in supplying water for community use.

Our main message, based on the material we present in this overview paper, is that defining the "success" of a sand-storage dam-or any technology for that matter-is not straightforward at all. For sand-storage dams specifically, two issues seem to be important:

- A dam would need to store an amount of water that is different enough (as in more) than what the existing riverbed would store without a dam - this relates to the extra water that dams bring to users, either in terms of volumes or in terms of availability over time.

- The water from a dam would have to be useable (in terms of access, quantities and qualities) to users-in case the water cannot be accessed for technical or socio-political reasons or cannot be used because of quality problems, a dam would be less effective.

We do realize that both criteria are both related and subject to further specification-what is "different enough," who defines when access is meaningful, etc. Nevertheless, separating between these two issues would allow for assessing whether dams make a difference in terms of water availability, or in terms of who profits from that water. In terms of hydrology, structural and hydro-geological properties of dams are important as explanatory factors why dams may (not) work. In terms of use, locations of dams and links to communities becomes vital.

Below, we start with providing an historical overview of water harvesting and related issues in Kenya and Kitui. Then, we start our assessment by presenting the results of a recent survey on different water provision technologies in Kitui. It becomes clear that sand-storage dams do not perform well, even though their performance might be less worrying compared to some other technologies. Then, we discuss the (related) issues of community involvement, water use and hydrological functioning. Finally, we suggest a research agenda that could strengthen both insights in the functioning of sand-storage technology in all its facets and further policy support for (new and existing) sand-storage dams.

\section{TRACING WATER FOOTPRINTS FROM PRE- TO POST-COLONIAL TIMES}

In pre-colonial Kenya, although efforts to improve access were needed, generally humans could live within easy reach of 


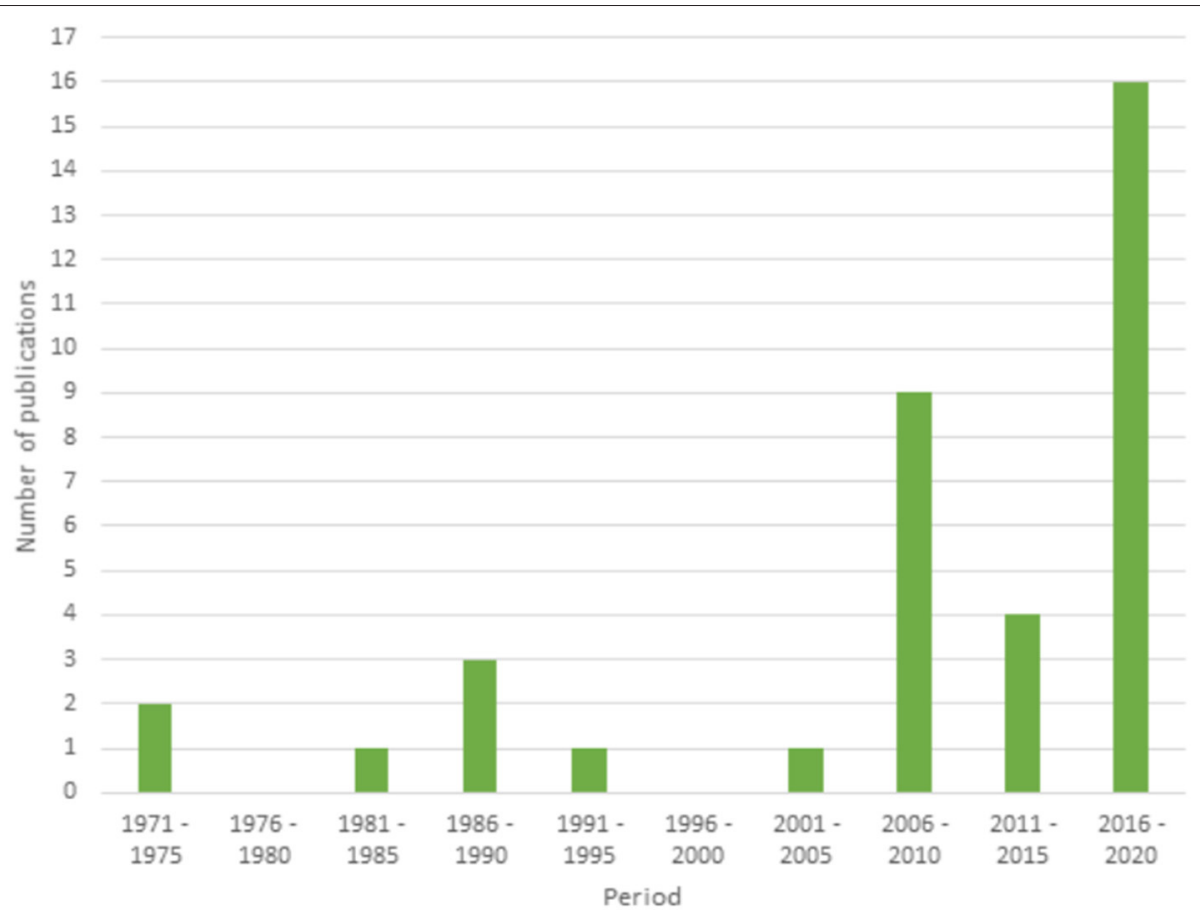

FIGURE 2 | Number of publications on sand-storage dams in the last 50 years.

a water resource that met their needs throughout the year (Parker, 2019). This was not unique to Kenya; all known global civilizations started near a water resource. Droughts did have different impacts compared to today, given the lower number of people depending on water sources and natural vegetation, forests and rich wildlife being more abundant and available, providing enough to eat (UNDP, 2007). Furthermore, the rich vegetation maintained enough recharge of groundwater aquifers that ensured rivers, lakes and springs did not dry up. Without suggesting that water was equally accessible to all, it seems safe to suggest that-given the lower number of people and more farm-based resource use-stress on water resources was relatively low. Farming activities were concentrated near the water resource where water needs, including cooking, could be met. Water to be used at the home (by humans and animals) had to be carried from the source to the farm.

As detailed in Parker (2019), this pattern of activities changed drastically during the colonial era, as vegetation was cleared to give way to commercial crop production. The Pokomo people offer a good example, along the Tana River. In the 1950s, they were forced out to create room for settling the mau mau dissidents as cheap source of labor-a process with highly negative consequences for both groups involved, and resulting in clearing of indigenous vegetation. Likewise, in the highlands where water is adequate, large swathes of forests in Kenyas' "water towers" were cleared to create what became known as "white highlands," dealing a blow to the natural ground water recharge process and adversely affecting water resources in larger regions. Development of irrigation projects started-reaping water where they did not sow as they required huge water quantities against little recharge to the source. These practices and policies over time triggered a water crisis that has continued to escalate, especially because a rise in population has created even more stress on available water resources.

Displacing populations disrupted local institutions that managed their water resources. As confirmed by Nilsson and Nyanchaga (2009), these traditional institutions had homegrown rules that were enforced to control, develop and maintain water resources. Following the disruption in colonial times, permanent water resources started drying and pollution became a concern. A tipping point seems to have been reached, with social institutions and water resources in disarray. New approaches were needed to help protect or increase water access and improve water resources management. The (colonial and Kenyan) governments responded by coming up with policies to address these problems, but water scarcity continued to be escalated (Mutui et al., 2016), especially due to a growth in population and industries-with climate change coming into the picture too (Mwangi et al., 2020). As such, for more than half a century, successive Kenyan governments have not been able to guarantee all citizens safe access to water. It is clear, however, that under those same governments, a small societal group did manage to profit from government through (mal)practices wellcaptured by Wrong (2009).

The result of this imbalance is a sharp decline in per capita water availability in the last 60 years in Kenya (Figure 3). In response, people have looked for other ways of finding manageable, sustainable and affordable solutions to have access 


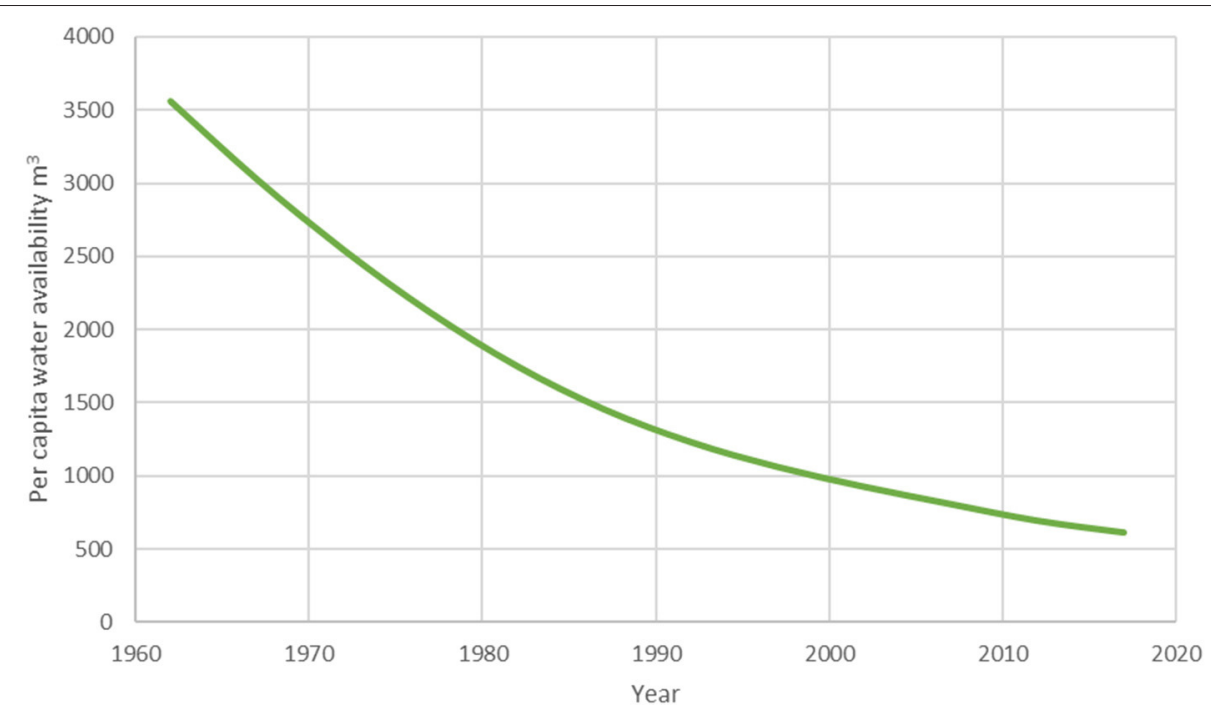

FIGURE 3 | Declining in per capita water availability in Kenya (FAO, 2019).

to water. In principle, these needs are well-met by rainwater harvesting technologies collecting and storing runoff water from a defined catchment for later use, which is why projects of that type are widely found in Kenya (Ngigi, 2003). The popular phrase "Utavuna ulichopanda" ("Reaping what you sow") that echoes through Kenya's landscapes, finds application in access to water through different rainwater harvesting, storing water in many shapes of reservoirs, such as tanks, cisterns, drums, or ponds. Of interest to this paper, in Kitui, Machakos and Makueni counties, water storage in sand-storage dams is much more developed than elsewhere in Kenya. From these three, Kitui County must currently be the global leader in sand-storage technology, at least in terms of dam numbers - if not attention in the scholarly literature, as mentioned earlier.

\section{SAND-STORAGE DAMS IN RELATION TO OTHER WATER TECHNOLOGIES}

In general, the Kenyan populace has embraced rainwater harvesting (Black et al., 2012) for several reasons, including large portions of the country categorizing under arid and semiarid lands (ASALS), increasing population, and declining rainfall reliability (attributed to anthropogenic issues) over the decades. Sand dams are a rainwater harvesting technology only feasible where seasonal sandy rivers occur. As such, it is a technology found in the arid and semi-arid regions of Kenya, with Kitui being the global hotspot whose fame has contributed to it being the most studied and documented region with this type of dams. In Kitui County, surface water sources are scarce. The rainfall is little and unreliable. Traditionally, the seasonal sand-filled riverbeds are the main sources of water. The seemingly dry sand contains water beneath the surface. The residents simply dig holes into these riverbeds to reach the water, which is then carried home in containers, either on people's back or by donkeys. Over time, many seasonal riverbeds could not supply enough water, mainly due to an increase in demand. In addition, increased levels of prosperity implied enhanced water demand, to a point of motorized pumps being in use-a development further escalating both scarcity and inequality. Among new water sources that have been mobilized are earth dams, boreholes, shallow wells and water tanks. Sand-storage dams are relatively new in Kitui: despite dams known from the earlier $20^{\text {th }}$ century, most dams have been built after the 1990s.

In Kitui County, the dam body itself (the impermeable barrier across the riverbed) is mainly built in masonry work (Figure 4). How many sand-storage dams are functioning today is subject to some speculation. There are an estimated 4,000 dams globally (Excellent Development, 2015), with an impressive 50\% of these constructed in the South Eastern Kenyan counties of Kitui, Machakos and Makueni. Although these numbers remain subject to scrutiny, it is very likely that South Eastern Kenya has indeed the highest concentration of sand dams on the globe. Starting in the 1990s, Kitui County has been a region of intensive construction of sand-storage dams. Estimates of how many dams have been built go from 600 to 1,800; our own estimate based on recent field work (Ngugi et al., 2020) suggest that Kitui County counts 1,500 sand-storage dams. In Kitui as much as in other semi-arid regions of Kenya with seasonal and sand-filled rivers, sand dams aim to increase the duration that water lasts in a sandy riverbed after a rainfall event and (especially) after the rainy season. In some dams, however, the water table descends quickly. As water users follow the descending water table by making the holes in the riverbed deeper, these pits can become dangerously deep as the dry period progresses.

Where sand dams have been successful in improving water access, water tables descend much slower (Thomas, 2000). This implies that more water has become available from the sand dams, resulting in increasing numbers of water-related socialeconomic activities, such as minor irrigation, keeping more 


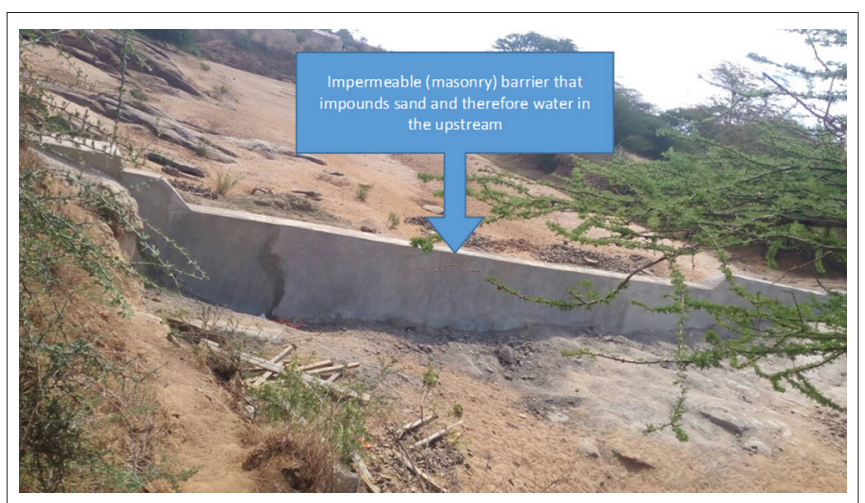

FIGURE 4 | A newly built sand-storage dam.

livestock, or making bricks for the construction sector. Besides these, increased access to water has resulted in reduced amounts of time spent on looking for water-especially by women and children (Pauw et al., 2008). In general, more people are able to engage in more economic activities. Not all the sand dams, however, have functioned as expected. Actually, many have failed to supply water during dry periods (Ngugi et al., 2020), an issue we will return to later in this paper.

First, we propose to position sand-storage dams in relation to other water provision technologies in Kitui. In order to assess the successes of different water resource development efforts, a survey project was done within Kitui County, aiming at several water resources projects, funded with individual, community, government or donor budgets. The aim was to find how functional these projects proved to be, with "functional" defined as "supplying water during the dry period." Reasons for a technology to function relate both being at an appropriate location and being structurally intact. The survey targeted the sub-counties of Kisasi, Kitui Central, Lower Yatta, and Mutomo, given their high likelihood of finding a large number of sand dams and other rainwater harvesting structures. A local person, well-versed with locations of several of the structures, acted as a guide, while each interviewee provided location and direction of the next rainwater harvesting structure. All interviewees were community members within the vicinity of the water projects in the survey. Both a questionnaire with the interviewee and a physical assessment of the water technology were applied to discover why technologies were (not) functioning. The questionnaire addressed issues related to project initiation, planning, implementation, training, community involvement, community observations and views. The questionnaire was structured to capture these issues for different funding sources: private, community-owned, donor-funded and governmentsponsored. Maintenance of structures appeared as a major issue to be explained.

Most (86\%) of the water resources were "gifts," (mainly) from the international donor community, while $9 \%$ were private and $5 \%$ were government-sponsored. With 52 sand dams, 35 shallow wells, 12 tanks, 5 boreholes, 3 earth dams and a largerscale pipeline being surveyed, most of the water resources were sand dams. Fifty out of the 52 dams were donor-funded. The second most abundant water resource, shallow wells, appear to accompany sand dams. As such, their functioning is more or less the same of sand dams. The third most common technology, tanks, showed a split in functioning: among those donated, none was functional, whereas all privately owned tanks were functional. Boreholes, though rare, offered a more reliable water source, as they were able to supply water during the dry periods between the rainy seasons-although one borehole was reported to have dried out. An interesting source of water was the government-sponsored pipeline, which provided a fairly reliable source of water from the Masinga hydroelectric dam. The pipeline was reported to fail occasionally, but apparently is always repaired and largely reliable. The water was metered, with resulting charges being set proportional to water consumption.

As Table 1, showing an overview of the results of the questionnaire for each water resource technology, suggests, many water projects in Kitui are not fully functional. This is especially the case for the ones, that were donated to communities. Sand dams may not be the worst functioning technology, but with the majority not being functional, the amount of failed dams remain high. Table 2 provides an overview of typical issues related to different types of technologies. The overall observation appears to be that in Kitui, those technologies that have been provided through donations have generally failed to provide enough reasons or options for water users and other stakeholders to arrange repairs and maintenance for water resources, when needed. Considering the arid conditions in Kitui County and the accompanying severe water scarcity, this picture of rather unsuccessful investments in (access to) water resources should provide a springboard for reflections on better ways to improve access to water. It would be prudent to provide water resources within the categories that render themselves to more sustainable provision-which appear to favor private and governmentowned sources.

\section{ASSESSING SAND-STORAGE DAMS}

In Kitui County, much attention toward improving access has gone into sand dams. Sand dams are not necessarily cheap, costing at least some 5,000 US Dollar in materials and labor costs for expertise (masonry worker). This cost estimate from Ertsen and Hut (2009) does not include full costs for labor, as it is based on budgets for NGO-supported projects with communities providing free labor (and food). Such high costs could easily explain why just a few dams are private. Furthermore, donors would prefer projects that render themselves to community provision, such as sand dams and shallow wells as opposed to tanks. The communal tanks assessed in the survey were related to social institutions, such as churches and schools. However, this link does not seem to have made the resulting technologies more reliable. In relation to sand dams developed by the Kituibased NGO that has assisted in building most of the sand dams in Kitui County, Ertsen and Hut (2009) observed that strengthening communal organization appears as a major goal from the start. 
TABLE 1 | Overview of functionality of water projects in Kitui.

\begin{tabular}{|c|c|c|c|c|c|c|c|}
\hline \multirow[t]{2}{*}{ Water resource } & \multicolumn{7}{|c|}{ Ownership type } \\
\hline & Functional & Non-functional & Functional & Non-functional & Functional & Non-functional & Total \\
\hline Sand dams & 18 & 32 & 1 & 1 & & & 52 \\
\hline Shallow wells & & 32 & 2 & & & & 34 \\
\hline Earth dams & & 2 & & & 1 & & 3 \\
\hline Pipelines & & & & & 1 & & 1 \\
\hline Totals & & 93 & & 10 & & 5 & 108 \\
\hline
\end{tabular}

TABLE 2 | Problems related to water technologies.

\begin{tabular}{ll}
\hline Water resource & Identified problems \\
\hline Sand dams & Broken walls, river migration, dry, eroded wing walls \\
Shallow wells & Vandalized pumps, open pits, abandoned \\
Tanks & Missing taps, poor aligned gutters and down pipes, broken \\
Boreholes & Broken pump, dry \\
Earth dams & Silted up, dry \\
\hline
\end{tabular}

In the Kitui dam construction efforts, women play a major role, providing most of the labor and food-provisioning efforts. It is mainly the role of the women and children to obtain water from sand dams and other sources, which could be the reason for the high turnout by women during community works to build sand dams. Furthermore, the problem of aridity has made many men seek employment in major urban centers, especially Mombasa or Nairobi, leaving women and children behind (Ngugi et al., 2020). During construction of water resources, such as tanks, earth dams and sand dams, qualified technicians-who are mainly menare employed to provide the skilled labor demanded for each technology. To what extent this gender disparity could be a contributing factor toward failed management and maintenance of water resources requires further study. In the combined absence of technicians and the men in the village, the women may not have the skills or interest to engage in maintenance efforts, especially when associated with the responsibility of men-such as repair works.

This process may also relate to the observation, that organizing a community for sand dam construction did not lead to a clearer community leadership and organization related to decision making on dams. The lack of asset management for collective efforts like sand-storage dams had been reported earlier (see Ertsen et al., 2005), and was clearly confirmed with the recent survey-if not emphasized even more. The importance of private vs. communal property for water resources in relation to use and maintenance of the resource stands out strongly as a new issue that needs to be considered. One would assume that in a region experiencing water scarcity, like Kitui, the efforts and resources for investment, proper management and protection of water resources would somehow result in clearly identifiable ownership. The survey results suggest that the issue of ownership vs. responsibility needs to remain high on the scholarly and policy-oriented agenda (see also Mogaka et al., 2006 and GOK, 2007). It is clear that ownership is not an issue specifically reserved for sand-storage dams only. For many technologies, simple repair works fails to happen due to poorly defined water resources ownership, leading to questions like who stops metal rods from being vandalized from a sand dam, who stops a neighbor from coming for water from your donor aided tank, and who can protect a borehole from hostile pastoralists that know you never built it in the first place? In some bizarre cases, family members have turned against each other over issues of water ownership. In a number of cases from the survey, masonry tanks have been converted into houses, dams have been abandoned and boreholes have lost valuable parts. Apparently, the water systems that are introduced by donors are not taken up in existing or new communal arrangements for management and operation of these systems.

\section{Water Use}

In Ertsen and Hut (2009), the issue of water use from sand dams was only discussed in general terms. Hut et al. (2008) clearly show that water use can affect the longer-term effects on groundwater levels, but that in general, household water use, including small scale agriculture, and bank infiltration can go hand in hand. The location of users in relation to the dam and the river would be of influence, with users closer to both being in a favorable position. We are not aware of studies that specify these issues of (locationbased) access to water from sand dams. The recent studies we can present provide some new insights on water use from sand dams in Kitui-which reflect relevant issues including location, perception and access.

A study by Strohschein (2016) assessed water use in 27 sand dams in the Kiindu catchment, near Kitui Town, combining field work and hydrological modeling. Local conditions and water exploitation were assessed by means of trans-sectional walks and semi-structured interviews. Small as the Kiindu catchment may be, water extraction and use appeared to depend to quite some extent on differences in catchment properties along the river. Broad riverbanks and riverbeds can store more water, which is 
used for irrigated agriculture on the riverbanks. At the same time, keeping the dams that need to cross these wider rivers functioning may be harder, as finding stable rock foundations may be less easy and potential erosion of the riverbanks may threaten the dams. The steeper slopes and narrower riverbeds found in the upstream parts of catchments usually combine with lower depths of the sand body in the riverbed. These combined properties make it easier to build and maintain dams, but at the same time explain why irrigation is less viable upstream. Strohschein (2016) confirmed that sand dams are less stable than commonly assumed. 18 years after the construction of most of the dams in the area, most dams have failed at least once (as they developed cracks or partially collapsed) - with most failures located in the wider downstream area. Not all dams appear to have been repaired.

\section{"An assessment of the whole Kiindu catchment would have averaged the effects of sand storage dams and would have led to the conclusion that (1) about $50 \%$ of the sand dams failed and (2) about $50 \%$ of the failed sand dams have been repaired, (3) around sand storage dams about two plots on the riverbanks would be irrigated and (4) walking distances would be reduced by $1 h$." (Strohschein, 2016)}

Why certain sand dams are repaired while others are not, could not be explained based on the data, although observations suggest that it is more likely that a dam will be repaired when it contained water that could be used in the vicinity of a sand dam. This finding may suggest that individual rather than communal access to a dam may be a factor that influences the decision to invest further in a broken dam-an observation that would be in line with the results found in the survey discussed earlier. For the catchment, water use could be explained when taking into account (1) the amount of water available, (2) the effort (and capital) needed to extract water, (3) the possibility to generate additional income (mainly by developing irrigated agriculture nearby-making bricks for sale, another common use of sand dam water, was not reported in the study), (4) water quality and (5) the availability of alternative water sources. However, these different factors and their interactions depended on specific settings within the same (relatively small) catchment. As such, it would be difficult to consider overall water use resulting from sand dam interventions. Transferring the experience gained in one catchment-which is already showing such diversity-to other catchments in the Kitui area remains a challenge.

Recent field work by Brummelkamp (2020) confirms this observation of variety within relatively small regions. Focusing on water access, with attention for parameters like distance, time, water quantity, water quality and reliability of a water source, two communities were studied. The study found both differences between and within communities. Overall, it is clear that proximity toward a dam-resulting in shorter water fetching times-is seen as a positive aspect of structures like sand storage dams. Concerning the use of that water, however, distinctions can be found. For example, some water users mobilize larger water volumes for domestic use, mainly because of their large households. Especially in the dry periods, these users' abilities to fetch water are influenced by the order of fetching water, with users queueing and waiting their turn. Some users, especially those closer to the dam, can irrigate crops with the more easily available water, providing financial benefits as well.

Within one community, a gender and age distribution between users was found (Brummelkamp, 2020). A group of mainly female water users value water quality above average, as they indicated changes in taste and odor of water sources to be a problem. In one of the catchment reaches, water was considered as saline. Previous studies on water quality indicated this as a problem to be addressed through effective sanitation practices as well as water disinfection (Ndekezi et al., 2019; Quinn et al., 2019). In earlier field work, Borst and De Hass (2006) measured electrical conductivities, and found these to be fluctuating over the season. The salinity source is likely to be saline rock. Strohschein (2016) found water quality to be a relevant factor explaining why dams are regarded as useful and worth investing time and money in. Community members close to a dam with lower water quality regularly fetch water from other sources further away. Higher amounts of good quality water result in more people and livestock using it, with the latter threatening water quality through urination and defecations.

Brummelkamp (2020) found that user satisfaction with the dam was linked to different aspects. In both communities that were studied, shorter fetching times for dams were valued positively (see also the findings by Pauw et al., 2008). Differences between communities and users were also found. In one community, a group of mainly youngsters valued the shorter water fetching times, but these water users were even more satisfied with the options that dams offered for social interaction. In another community, the shorter fetching times were appreciated, but also considered less important, as the reliability of the water source from the dam was less. Sand harvesting from the dam (mainly for building purposes) was mentioned as a problem. At the same time, this same community includes a group that use dam water to irrigate vegetables and fruits. The results from these two communities clearly show that a shared appreciation of a relatively clean water supply, can be based on different reasons, which do not necessarily overlap or align.

\section{Dam Hydrology}

Whether sand-storage dams actually hold water, and of which type, depends on the local hydrology of the dam catchment. Much work on the hydrology of sand dams is based on measurements in a single season of one dam, or is based on modeling. Useful as these studies are, it was Ngugi et al. (2020) that presented for the first time a more comprehensive overview of the water holding capacity of sand-storage dams. From the 116 masonry-wall sand dams in the Tiva catchment in Kitui County, only about $42 \%$ was able to meet household water demand throughout the dry period between the short and long rainsa rather staggering $58 \%$ of the dams could not. Figure 5 shows that for the second dry season, the number of dams holding water was even lower at $36 \%$, which can be attributed to the variability in severity of the inter-seasonal droughts. Even worse, perhaps, is that $16 \%$ of the dams (after the short rains) and 23\% (after 


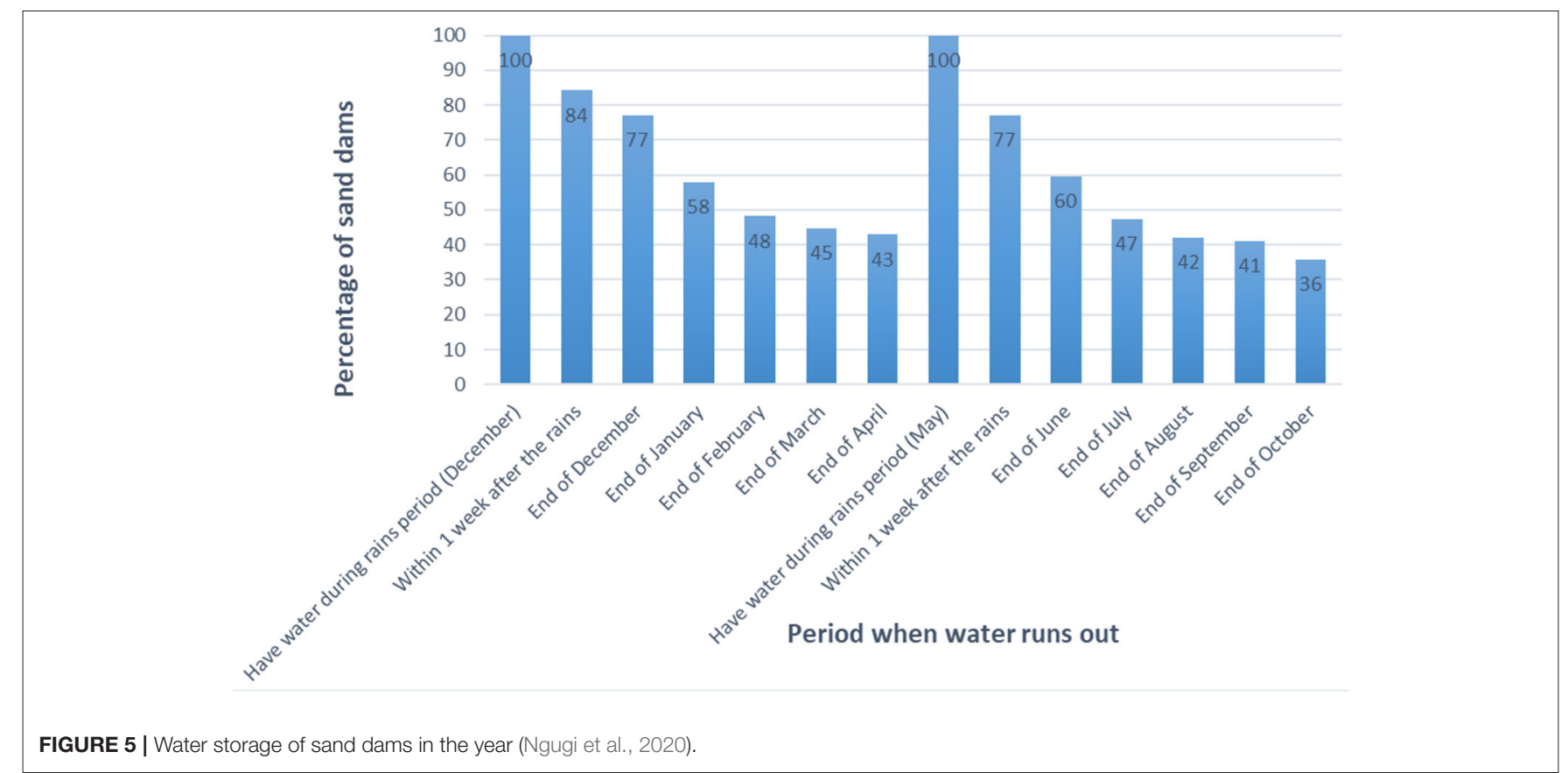

the long rains) dried out very soon, as in within weeks, after the rains stopped.

Dry dams leave water users with the challenge of identifying alternative water sources, including those already mentioned above (other sand dams or riverbeds, hand dug or shallow wells, springs, water tanks from household roof rainwater harvesting, earth dams, boreholes and in some cases piped water). The observation that many sand dams in the Tiva catchment did not increase access to water could be mainly attributed to poor site identification, which may relate to NGOs and government agencies lacking adequate guidelines for site identification. However, Ngugi et al. (2020) showed that proper site identification is rather complicated in itself, with some factors that are usually suggested to guide proper site identificationlike soil characteristics, topography and geology-possibly not being the extremely useful factors they are supposed to be. For other factors, like the amount of average rainfall, rock outcrops, and water indicating vegetation, the predictability for the water retention rate of dams remained low as well. These observations led to the conclusion by Ngugi et al. (2020) that regarding sand dam siting, design and construction, there is a clear need to reconsider standard guidelines and procedures.

\section{THE EFFECTIVENESS OF SAND-STORAGE DAMS}

As we have discussed above, the issues of dam management, water use and hydrological functioning are closely connected to the location of sand-storage dams. Many studies on the hydrology of sand dams suggest that those sand dams that are able to hold water for longer periods, must be recharged from sources outside the direct riverbed itself (Diettrich, 2002; Borst and De Hass,
2006; Hut et al., 2008; Quilis et al., 2009). Additional recharge can be provided by adjacent open aquifers or by (sub)surface inflow from the riverbanks or further upstream-potentially even from beyond the immediate catchment area of the dam itself. For ephemeral streams, which flow in response to a rainfall event and are almost always above the water table, impermeable riverbed and banks would ensure water stays within the sandy depositions, reminiscent of a perched aquifer. Obviously, such geological features are rather the exception than the rule: some sand dams erected on ephemeral streams lose all their water in a matter of hours, as water percolates downwards to the deeper water table (Ngugi et al., 2020). It is clear that in circumstances where the water table is several meters below the riverbed, an isolated dam may do little to nothing in terms of sustaining water tables-rendering the dam of limited value. This may explain why dams erected on ephemeral streams have failed to supply water during the dry periods.

These issues of location in relation to catchment properties are illustrated in Figure 6. Dam SD1 may raise the water table in the area close to the sand dam, but in these head areas, the original water table might be several meters below the surface. This might mean that only a small localized rise in water table will be achieved-which would not substantially increase access to water during the dry periods, as we already have seen. Building dams on locations further downstream, like SD2 and SD3 might create more favorable conditions (as Strohschein, 2016 also found). Especially SD3, built further downstream, may raise the (perhaps already higher) water table to the extent that scoop holes in the bed or shallow wells in the banks become (even more) useful. This is the likely scenario in what Quinn et al. (2019) observed in Kenya, where a sand dam continuously received and lost water, yet continued to be a reliable source of water. In this example landscape, SD4 could profit from an impermeable layer creating 


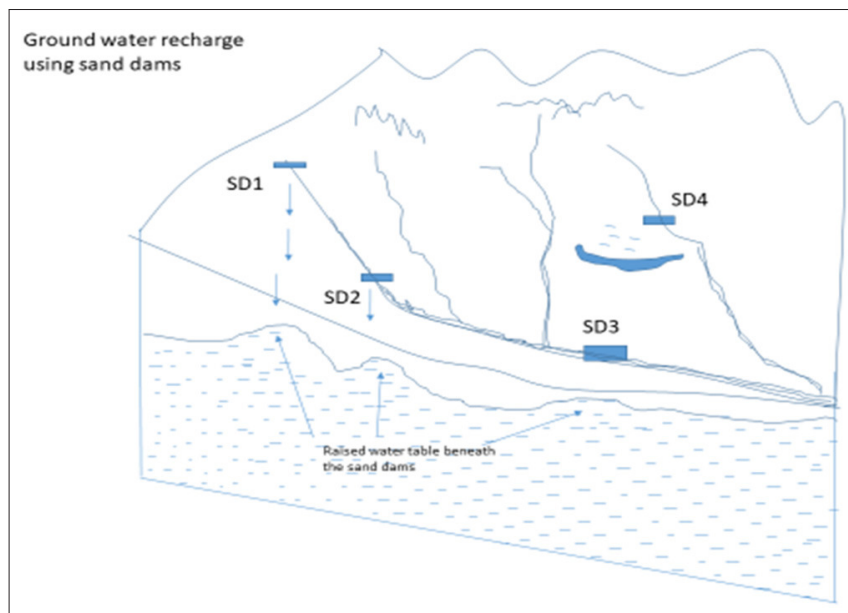

FIGURE 6 | Sand dams at different locations in a catchment.

a localized raised water table, accessible through shallow wells. Depending on the distance between dams, more significant rise in water tables can be reached when several sand dams are present along the same stream in what is referred to as a cascading system of sand dams. This multiplier effect has been studied to some extent by Quilis et al. (2009) and Strohschein (2016), but much remains to be studied on how the effective rising of water tables is influenced or can be improved by building dams in cascades throughout the catchment.

Without suggesting that it is sufficient for success, it seems to be logical that for sand-storage dams to be a useful investment of time, labor and money, they need to hold water for a period of time long enough for many water uses to be possible. For sand dams to function in such a way, at least two key properties need to be considered:

1. the aquifer that is developed and/or sustained, and

2. the sediments that need to hold the water.

\section{Aquifer Development}

Observations made in Kitui County over runoff generation paint a picture of limited infiltration, which implies much of the water ends up in direct runoff (Hai, 1988). Rainfall in Kitui County occurs in intensive storms, which greatly contributes to very high surface runoff flows. As such, little of the rainfall ends up in groundwater recharge. The combination of high direct runoff, limited groundwater recharge and continuous abstraction of water from the subsurface results in a continuous decline of the water table. Once the water table descends below a specific threshold, below the riverbed itself, even sand dams cannot function well anymore, as any water they impound in the subsequent rainy seasons will be quickly lost to the lower water table. The success of sand dams in supplying water during the dry period is dependent on maintaining contact between the riverbed and the water table. In regions downstream, with high stream orders, where the seasonal rivers flow for longer periods of time and the water table is usually higher and in contact with the riverbed, sand-storage dams promise to store water for a longer period, from which users can continuously draw water from the adjacent aquifer as the drought intensifies [again as observed by Strohschein (2016)]. This is the main reason sand dams built in streams of a high order are able to supply water for longer dry periods compared to those of smaller stream orders (Ngugi et al., 2020).

To increase the number of sand dams that are able to supply water in smaller streams as well, catchment-wide rainwater harvesting through additional methods such as recharge wells and infiltration pits, would be a suitable strategy - which has not been attempted yet in Kitui. The County receives an average annual rainfall amount of about $500 \mathrm{~mm}$. Kitui County rainfall records reveal that the largest part of rain will become available in four major storms, each yielding up to $100 \mathrm{~mm}$ of rainfall in $24 \mathrm{~h}$. With a runoff coefficient of about 50\% (Hai, 1988), some $250 \mathrm{~mm}$ will become direct runoff. Each single storm of $100 \mathrm{~mm}$, allowing for evaporation losses of $8 \mathrm{~mm}$ per day, would allow $42 \mathrm{~mm}$ of water to infiltrate, refill the soil moisture storage and feed the water table. For four storms this translate to $168 \mathrm{~mm}$. One of the dominant soil types in Kitui is sandy loam, which has an available water capacity of about $150 \mathrm{~mm} / \mathrm{m}$ (Brouwer and Heibloem, 1986). Given that soil depths in Kitui are in the order of meters, the available water for infiltration is clearly low. Given the receding water tables and deteriorating rainfall characteristics as predicted by climate change models (Ochieng et al., 2016; Gladys, 2017), Kitui County should begin to consider its catchment-wide water storage opportunities beneath the surface. Such a strategy could create opportunities for increasing water access from sand dams and other interconnected resources. When runoff can be targeted to go into infiltration, the additional soil moisture storage could eventually raise the water table. This would increase the water retention capacity of the landscape. There is need to translate such desk calculations to field based experiments.

\section{Contested Sediments}

Another key process emerging for successful water supply by sand dams, linking spatial considerations to temporal matters, is how the catchment yields coarse textured sand to be transported and deposited upstream of the erected barrier. In other words, how does soil erosion assist water harvesting in riverbeds? One aspect of this sediment issue is to what extent textural characteristics of sediments transported to and within the riverbed change with time. This is not just a natural process: sediments are a contested resource nowadays (Mungai et al., 2000; Kivuva, 2010; Mattamana et al., 2013; Ngundo, 2014). Harvesting sand for construction purposes-with sand dams being popular as these have higher volumes of useful sedimentsis actually an important competing interest for sand. The impact of sand harvesting is large in counties close to cities like Nairobi (Gitonga, 2017) or with more intensive urbanization in the county itself. As such, Machakos County has more severe issues regarding sand harvesting), but it would be just a matter of time before the problem gets worse in Kitui County as well. Sand harvesting offers direct financial rewards to those involved, but leaves a tale of destruction of the water resources. Sandy rivers subjected to sand harvesting end up with deteriorating water quality and quantity trends (Gitonga, 2017). 
Changes in land use can make problems of sediment effectiveness in sand dam catchments even worse. Long before Kenyans started making use of sand for commercial construction purposes, landscapes in Kitui were well-covered with indigenous vegetation and the riverbeds were filled with sand. With an increase in population, resulting in further land clearing for cultivation (Kiruki et al., 2017), the slower and longer-term process of filling riverbeds with sand has been replaced by a process producing higher volumes of catchment soil consisting of smaller-sized particles ending up in rivers (Petersen, 2011). As such, the increase in smaller soil particles in riverbeds is directly proportional to the increase in population and built and/or cultivated environments, which are all factors linked to increased soil erosion. Excessive erosion may result to siltation of sand dams, with high depositions of clay and silt particles. Sand dams may have become "silt traps" (Petersen, 2011). When the high demand for sand by the construction industry results in "old" sand in the riverbeds being removed, this coarser material could be replaced by a mixture of clay, silt and sand in a ratio reflecting the textural composition found in the farmed land-but with less water retention and extraction properties.

To complicate this image even further, the increase in population has resulted in more intensive cultivation on land holdings that have continuously reduced per capita. At the same time, an increase in soil and water conservation measures can be observed as well (Figure 7). This (unexpected) observation of "more people, less erosion" was first documented in 1994 in Machakos County (Tiffen et al., 1994). Since then, the goingtogether of a growth in population alongside increased greening has been confirmed (Critchley, 2011). However, beneficial as soil conservation is, well-conserved catchments may not be capable of yielding enough coarse sand, as the heavier soil particles would be the first to be held back by the soil and water conservation measures. As a result, mining coarse river sand amidst land cover deterioration may result in riverbeds being less able to supply water. This Pandora's Box of Sediment is further shaped by climate change shifting rainfall into even more intensive storms in the future. As time unfolds, sand dams will continue to respond to the various natural and anthropogenic manipulations, but it is clear that sand dams with their coarse sand removed, may never be restored to their original state in the near future.

\section{TOWARD DEALING WITH COMPLEX CHANGES}

Kenya faces worrying trends in per capita water availability. Rainwater harvesting could be a tool to fill the gap; for Kitui County sand-storage dams are a key technology. The recent findings that we presented above, however, suggest that these dams are not as appropriate for rainwater harvesting as has been suggested in much of the debate. We also indicated some avenues to explore when building sand dams for rainwater harvesting. Sand-storage dams are spatially limited and function very locally in terms of hydrology. Treating the whole watershed to increase water infiltration and raise the water table, can support sandstorage dams becoming more successful. This calls for more work on the whole watershed or sub-watersheds to improve water flow in the riverbeds. "Happy" rivers are like juicy fruits on a healthy tree. It takes a lot of energy for that tree to eventually bear fruit. In this analogy, the tree is the watershed and for it to thrive, larger efforts are needed. The different processes that need to be taken into account when discussing success of sand-storage dams, let alone when developing new dams and/or a catchment program as hinted above, create a highly diverse picture of sand-storage dam practices.

There is considerable diversity in the sand-storage dam situation in Kitui County, which is usually presented as homogenous and successful-as is also found for other groups that are often perceived as homogeneous, like farmers in a region (Brodt et al., 2006; Vennet Vander et al., 2016). Brummelkamp (2020) strongly suggests that further research to explore underpinning reasons for water use will be valuable. We imagine such research exploring existing ideas and preferences in a community before designing a specific intervention would be useful as well. Careful analysis of societal settings in terms of diversities within stakeholder groups avoids the risk that target groups are treated as homogeneous, rather than consisting of diverse people with varying characteristics. Such work will also allow to recognize differences in decision-making (Pannell et al., 2006; Doss et al., 2014; Mutenje et al., 2016; Wheeler et al., 2017).

Our discussions so far show the complex interactions between human users of different kinds, sand-storage dams, sediments, water, vegetation and many other agents in the Kitui landscape. We have suggested that the potential of sand-storage dams to increase water availability in Kitui is quite high, but that the current failure rate is high as well. In order to study why dams can become a success (in terms of water retention, management and use) or not, Schulthess (2017) developed an agent-based model $(\mathrm{ABM})$, as this allows studying interactions between different acting entities. The study defined "agency" as "having an effect on other acting entities," which allows including many of the interactions discussed above on similar footing in the model. The model itself was built using the field data provided by Strohschein (2016). Starting with a scenario mimicking current hydro-climatic conditions, the model provided sufficiently realistic dam performance results. With processes of interaction between agents appropriately modeled, other scenarios could be explored-in terms of climatic conditions, dam properties, and time period. Even when water availability is not restricted, the modeling results suggests a general trend toward social inequality within communities over time. In other words, the model suggests that socio-economic differences are likely to occur even in conditions without water scarcity-which is in line with field observations (Strohschein, 2016).

\section{BY WAY OF CONCLUSION}

Building the integrated understanding we discussed in this paper in order to deal with constraints and options of sandstorage technology in terms that are relevant for (parts of) stakeholder groups, would offer better options to reach longerterm benefits compared to implementing one "universal" strategy 


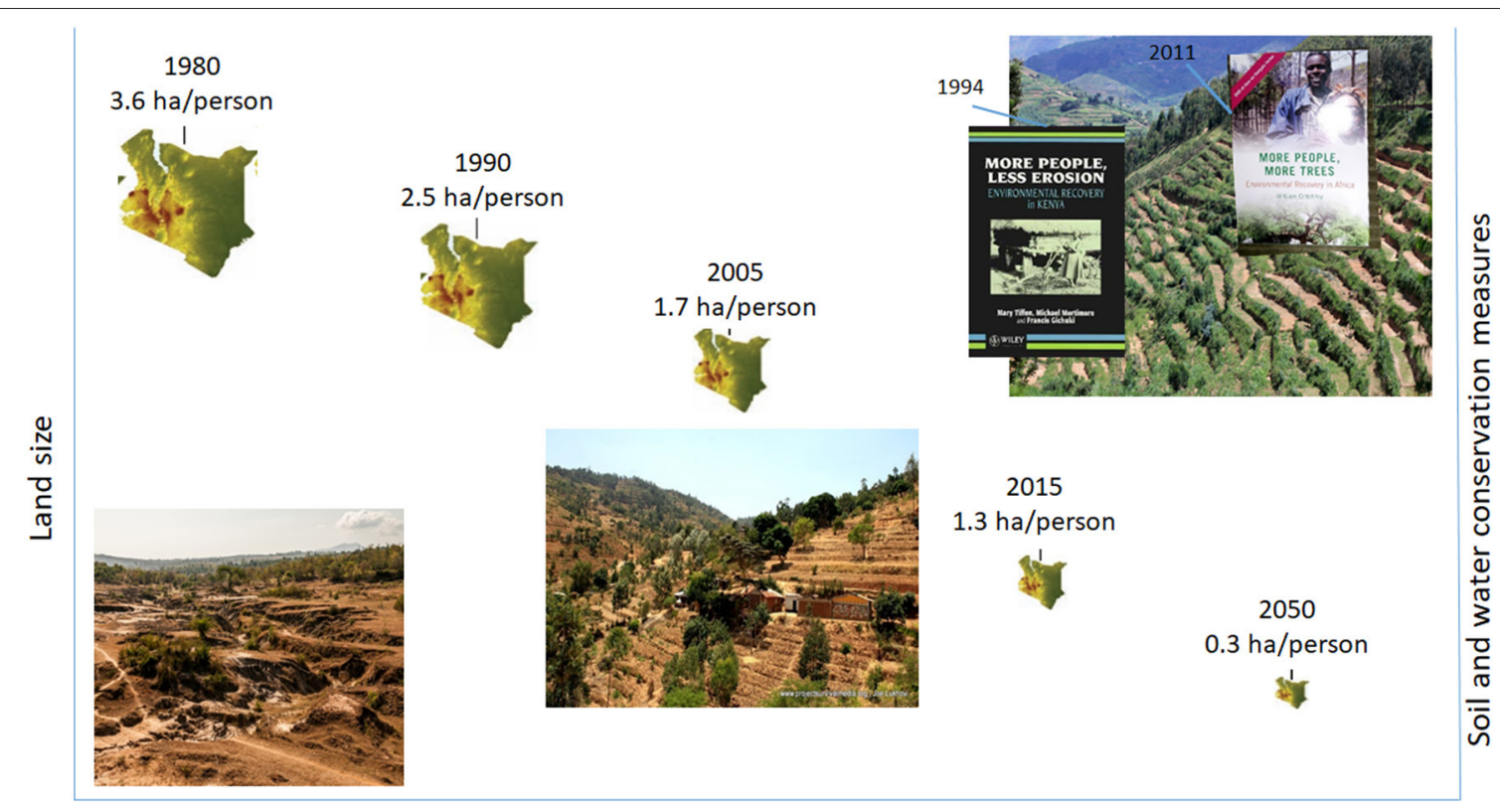

Shrinking per capita land availability and increase in soil and water conservation with time

FIGURE 7 | Conserve or not: Sand dams coarse sand restoration dilemma (Tiffen et al., 1994; Critchley, 2011).

when developing sand-storage dams. This issue of narrowdefined intervention approaches was already taken up by Ertsen and Hut (2009), when they suggested that the strength of the linkages between communities and dams may be negatively influenced by the construction-focused intervention process in most of Kitui's sand dam projects. Even when one assumes that sand-storage technology is suitable to provide water-and despite our discussions, there is enough evidence that this can be the case-it would still be extremely valid to adapt investments, innovations, technologies and policies to a diverse community, replacing "technology transfer" with "technology translation" (Garb and Friedlander, 2014). Key would be to center on what constitutes "success" of a sand-storage dam-or any technology for that matter. We defined at least two issues, storage and

\section{REFERENCES}

Benedicto Van Dalen, D., De Wildt, S., and Muendo, B. (n.d). Ensuring Resilience Through Community Sand Dams in Kenya. A GroundwaterBased Natural Storage Solution to Make More Water Available for Drinking and Irrigation. Available online at: https://gripp.iwmi.org/natural-infrastructure/ waterstorage/ensuring-resilience-through-community-sand-dams-in-kenya/ (accessed June 28, 2021).

Black, J., Malesu, M., Oduor, A., Kipruto, C., and Meerman, R. (2012). Rainwater Harvesting Inventory of Kenya. Technical Manual No. 8. World Agroforestry Centre (ICRAF).

Borst, L., and De Hass, S. A. (2006). Hydrology of sand storage dams: a case study in the Kiindu catchment (Msc. thesis). Vrije Universiteit, Kitui District, Kenya.

Brodt, S., Klonsky, K., and Tourte, L. (2006). Farmer goals and management styles: implications for advancing biologically based agriculture. Agric. Syst. 89, 90-105. doi: 10.1016/j.agsy.2005.08.005 usability, to be considered, but we do realize that both criteria are subject to further specification-what is "different enough," who defines when access is meaningful, etcetera. Achieving this type of approach requires a multi-sectoral approach and participation by all the stakeholders, with most likely a key role to be fulfilled by government agencies. People in the ASAL regions of Kenya would readily welcome interventions that bear promises of increasing access to water, such as improving access from the already existing sand dams or those likely to be built in future.

\section{AUTHOR CONTRIBUTIONS}

All authors listed have made a substantial, direct and intellectual contribution to the work, and approved it for publication.

Brouwer, C. A. G., and Heibloem, M. (1986). Irrigation Water Management: Training Manual No. 1 - Introduction to Irrigation. Rome: FAO.

Brummelkamp, J. M. (2020). Sand storage dams in Kitui-Kenya: community perspective on access to water an evaluation using Q-methodology (Msc. thesis). Delft University of Technology, Delft, Netherlands. Retrieved from: http:// repository.tudelft.nl/.

Critchley, W. (2011). More People, More Trees: Environmental Recovery in Africa. Warwickshire, UK: Practical Action; Slp Pap/Dv edition.

De Trincheria, J., Leal, W. F., and Otterpohl, R. (2018). Towards a universal optimization of the performance of sand storage dams in arid and semi-arid areas by systematically minimizing vulnerability to siltation: a case study in Makueni. Kenya Int. J. Sediment Res. 33, 221-233. doi: 10.1016/j.ijsrc.2018.05.002

Diettrich, E. (2002). Artificial Ground-Water Recharge by means of Subsurface Dams. Irbid Uni. Pub.: Jordan.

Doss, C., Kim, S. M., Njuki, J., Hillenbrand, E., and Miruka, M. (2014). Women s individual and joint property ownership: effects on household 
decision making. International Food Policy Research Institute. discussion: 1347. doi: $10.2139 / \mathrm{ssrn} .2483968$

Eisma, J. A., and Merwade, V. M. (2020). Investigating the environmental response to water harvesting structures: a field study in Tanzania. Hydrol. Earth Syst. Sci. 24, 1891-1906. doi: 10.5194/hess-24-1891-2020

Ertsen, M., Biesbrouck, B., Postma, L., and Westerop, M. (2005). "Community organisation and participatory design of sand-storage dams in Kenya,..in Civil Engineering and Geosciences, Water Resources, Delft University of Technology, eds T. Gossling, R. J. G. Jansen, and L. A. G. Oerlemans (Nijmegen: Wolf Publishers), 175-185.

Ertsen, M., and Hut, R. (2009). Two waterfalls do not hear each other. Phys. Chem. Earth 34, 13-22. doi: 10.1016/j.pce.2008.03.009

Excellent Development (2015). Excellent Development Annual Report 2014/15. UK.

Falkenmark, M., Fox, P., Persson, G., and Rockström, J. (2001). Water Harvesting for Upgrading of Rainfed Agriculture: Problem Analysis and Research Needs, SIWI Report II. Stockholm International Water Institute.

FAO (2019). AQUASTAT Database. Available online at: https://knoema.com/ FAOAQST2019/aquastat (accessed on February 27, 2021).

Garb, Y., and Friedlander, L. (2014). From transfer to translation: using systemic understandings of technology to understand drip irrigation uptake. Agric. Syst. 128, 13-24. doi: 10.1016/j.agsy.2014.04.003

Gitonga, E. K. (2017). Factors affecting sand harvesting in Machakos County, Kenya (MSc. thesis). University of Nairobi, Nairobi, Kenya.

Gladys, K. V. (2017). Rainfall and temperature variability and its effect on food security in Kitui county. Int. J. Dev. Sustainability 6, 924-939.

GOK (2007). The National Water Services Strategy (NWSS) 2007-2015. Draft. In Human Rights. Retrieved from: https://waterfund.go.ke/watersource/ Downloads/National\%20Water\%20Services\%20Strategy\%20Draft.pdf

Hai, M. (1988). Runoff harvesting for crop production in Kitui, Kenya (Msc. thesis). University of Nairobi, Nairobi, Kenya.

Hut, R., Ertsen, M., Joeman, N., Vergeer, N., Winsemius, H., and van de Giesen, N. (2008). Effects of sand storage dams on groundwater levels with examples from Kenya. Phys. Chem. Earth 33, 56-66. doi: 10.1016/j.pce.2007.04.006

Kiruki, H. M., van der Zanden, E. H., Malek, Ž., and Verburg, P. H. (2017). Land cover change and woodland degradation in a charcoal producing semi-arid area in Kenya. Land Degrad. Dev. 28, 472-481. doi: 10.1002/ldr.2545

Kivuva, M. (2010). Impacts of instream sand harvesting on water supply, a case study of river Thakwe, Makueni County (MSc. thesis). Kenyatta University, Nairobi, Kenya.

Mattamana, B. A., Varghese, S., and Paul, K. (2013). River sand inflow assessment and optimal sand mining policy development. Int. J. Emerg. Technol. Adv. Eng. 3, 306-317.

Mogaka, H., Gichere, S., Davis, R., and Hirji, R. (2006). "Climate variability and water resources degradation in Kenya: Improving water resources development and management," in World Bank Working Paper (Washington, DC). doi: 10.1596/978-0-8213-6517-5

Mungai, D. N., Thomas, D. B., Gichuki, F. N., Gachene, C. K. K., and Gachene, C. K. K. (2000). Environmental and land-use consequences of sand harvesting in Masinga division.

Mutenje, M., Kankwamba, H., Mangisonib, J., and Kassie, M. (2016). Agricultural innovations and food security in Malawi: Gender dynamics, institutions and market implications. Technol. Forecast. Soc. Change 103, 240-248. doi: 10.1016/j.techfore.2015.10.004

Mutui, F. N., Omosa, I. B., Cun-kuan, B., Oonge, and Gaitho, V. (2016). Kenya's water Resources : Scarcity or Sheer Mismanagement? Int. Res. J. Environ. Sci. $5,54-60$.

Mwangi, M., Kituyi, E., Ouma, G., and Macharia, D. (2020). Indicator approach to assessing climate change vulnerability of communities in kenya: a case study of Kitui county. Am. J. Climate Change 9, 53-67. doi: 10.4236/ajcc.2020.92005

Ndekezi, M., James, W. K., and Patrick, G. H. (2019). Evaluation of sand-dam water quality and its suitability for domestic use in arid and semi-arid environments: a case study of Kitui-west sub-county, Kenya. Int. J. Water Res. Environ. Eng. 11, 91-111. doi: 10.5897/IJWREE2019.0855

Ngigi, S. N. (2003). Rainwater Harvesting for Improved Food Security. Nairobi: Greater Horn of Africa Rainwater Partnership.

Ngugi, K. N. K., Gichaba, C. M. M., Kathumo, V. M. V., and Ertsen, M. W. (2020). Back to the drawing board: assessing siting guidelines for sand dams in Kenya. Sustainable Water Res. Manage. 6, 1-28. doi: 10.1007/s40899-020-00417-4
Ngundo, J. (2014). The effects of sand harvesting on water accessibility in muooni river (MSc thesis). Egerton University, Kenya.

Nilsson, D., and Nyanchaga, E. (2009). "East African water regimes: the case of Kenya," in The Evolution of the Law and Politics of Water, eds J.W. Dellapenna and J. Gupta (Berlin: Springer), 105-120. doi: 10.1007/978-1-4020-9867-3_7

Ochieng, J., Kirimi, L., and Mathenge, M. (2016). Effects of climate variability and change on agricultural production: the case of small scale farmers in Kenya. NJAS - Wageningen J. Life Sci. 77, 71-78. doi: 10.1016/j.njas.2016.03.005

Pannell, D. J., Marshall, G. R., Barr, N., Curtis, A., Vanclay, F., and Wilkinson, R. (2006). Understanding and promoting adoption of conservation practices by rural landholders. Aust. J. Exp. Agric. 46, 1407-1424. doi: 10.1071/EA05037

Parker, J. (2019). Water Shortages Have a History: How the Kenyan Colonial State Mismanaged a Resource and Endangered a Community. Perspectives on History. Retrieved from: https://www.historians.org/publications-and-directories/ perspectives-on-history/september-2019/water-shortages-have-a-historyhow-the-kenyan-colonial-state- mismanaged-a-resource-and-endangered-acommunity (accessed October 13, 2020).

Pauw, W., Mutiso, S., Mutiso, G., Manzi, H., Lasage, R., and Aerts, J. (2008). An Assessment of the Social and Economic Effects of the Kitui Sand Dams. Community Based Adaptation to Climate Change. Nairobi: SASOL \& Institute for Environmental Studies.

Petersen, N. (2011). Sand Dams or Silt Traps? Available online at: http:// www.samsamwater.com/library/Sand_dams_or_silt_traps.pdf (accessed May 13, 2015). 1-6.

Quilis, R. O., Hoogmoed, M., Ertsen, M., Foppen, J., Hut, R., and De Vries, A. (2009). Measuring and modeling hydrological processes of sandstorage dams on different spatial scales. Phys. Chem. Earth 34, 289-298. doi: 10.1016/j.pce.2008.06.057

Quinn, R., Avis, O., Decker, M., Parker, A., and Cairncross, S. (2019). An assessment of the microbiological water quality of sand dams in southeastern Kenya. Water(Switzerland) (Switzerland) 10, 1-14. doi: 10.3390/w100 60708

Ryan, C., and Elsner, P. (2016). The potential for sand dams to increase the adaptive capacity of East African drylands to climate change. Reg. Environ. Change 16, 2087-2096. doi: 10.1007/s10113-016-0938-y

Schulthess, K. (2017). Socio-hydrological modelling of the kiindu river catchment in Kitui district, Kenya (MSc. thesis). Technical University of Delft, Delft, Netherlands.

Strohschein, P. M. (2016). Exploring the influence of sand storage dams on hydrology and water use (Msc. thesis). Delft University of Technology, Delft, Netherlands.

Thomas, D. (2000). Where There is no Water. A Story of Community Water Development and Sand Dams in Kitui District, Kenya. Nairobi: SASOL and Maji na Ufanisi.

Tiffen, M., Mortimore, M., Gichuki, F. (1994). More People, Less Erosion Environmental Recovery in Kenya. Nairobi, Kenya: ACTS Press.

UNDP (2007). Kenya Natural Disaster Profile. In Enhanced security Unit. Retrieved from: https://meteorology.uonbi.ac.ke/sites/default/files/cbps/sps/ meteorology/Project\%20on\%20Disasters.pdf

Vennet Vander, B., Schneider, S., and Dessein, J. (2016). Different farming styles behind the homogenous soy production in southern Brazil. J. Peasant Stud. 43 , 396-418. doi: 10.1080/03066150.2014.993319

Wheeler, S. A., Zuo, A., Bjornlund, H., Mdemu, M. V., van Rooyen, A., and Munguambe, P. (2017). An overview of extension use in irrigated agriculture and case studies in south-eastern Africa. Int. J. Water Res. Dev. 33, 755-769. doi: 10.1080/07900627.2016.122 5570

Wrong, M. (2009). It's Our Turn to Eat: The Story of a Kenyan Whistle Blower. London: Harper Collins.

Conflict of Interest: The authors declare that the research was conducted in the absence of any commercial or financial relationships that could be construed as a potential conflict of interest.

Copyright $\odot 2021$ Ertsen and Ngugi. This is an open-access article distributed under the terms of the Creative Commons Attribution License (CC BY). The use, distribution or reproduction in other forums is permitted, provided the original author(s) and the copyright owner(s) are credited and that the original publication in this journal is cited, in accordance with accepted academic practice. No use, distribution or reproduction is permitted which does not comply with these terms. 